\title{
IMPACT OF NFERTILIZER RATE ON BARELY (HORDUM VULGARE) IRRIGATED WITH MAGNETIZED AND NON- MAGNETIZED SALINE WATER WITH APPLICATIONOF ${ }^{15} \mathrm{~N}$ STABLE ISOTOPE
}

\begin{abstract}
A. A. Moursy and A. H. El-Kholy
Atomic Energy Authority, Nuclear Research Center, Soil and Water Research Department, Abou-Zaabl, 13759, Egypt

Received: Nov. 23, 2019

Accepted: Dec. 8, 2019

ABSTRACT: The experiment was conducted at Soil and Water Research Department Greenhouse, was carried out to study the effect of different levels of salinity stress on the barely crop also Study the effect of the water magnetization to reduce salinity effect and ${ }^{15} \mathrm{~N}$ in plant parts. Lowest grain yield of $11.68 \mathrm{~g} \mathrm{pot}{ }^{1 b}{ }^{y} \mathrm{M}_{0} \mathrm{~S}_{2} \mathrm{~N}_{0}$. This decrease in grain yield was by the low $N$ fertilization and the salinity stress. Grain yield was $38.80 \mathrm{~g} \mathrm{pot}^{-1}\left(M_{0} \mathrm{~S}_{2} \mathrm{~N}_{4}\right)$ with an increase averaging $232.2 \%$. The lowest straw dry matter yield was $10.60 \mathrm{~g} \mathrm{pot}^{1}$ given by $M_{0} S_{3} N_{0}$. Plants werfaced difficulty to absorb $N$ because of salinity. The highest straw yield was $26.40 \mathrm{~g} \mathrm{pot}^{-1}\left(M_{1} S_{0} N_{4}\right)$ with $149.1 \%$. The highest straw $N$ uptake was 197.9 by M1N4SO with $343.7 \%$. The lowest $N$ uptake in grains was $117.9 \mathrm{~g} \mathrm{pot}^{-1}$ by $M_{0} S_{1} N_{3}$. The highest grains $N$ uptake was 372.9 g pot $^{1}$ by $M_{0} S_{2} N_{2} 216.3 \%$ increse $N$ recovery by straw ranged was 0.11 to $7.76 \mathrm{~g} \mathrm{pot}^{1}$ due to $M_{0} S_{0} N_{3}$ and $M_{1} S_{2} N_{1}$, respectively. The main effect of magnetization was an increase due to $M_{1}$. The main effect of salinity show an increase in $N R$ when the salinity was in medium rates. $N$ recovery by grains ranged from 0.65 to 25.14 $g$ pot ${ }^{-1}$ due to $M_{0} S_{0} N_{1}$ and $M_{1} S_{1} N_{1}$, respectively.
\end{abstract}

Key word: ${ }^{15}$ Nitrogen, salinity, magnetized water, barely crop.

\section{INTRODUCTION}

Magnetic water treatment is one such area, and the magnetic field applications have been known for centuries (Colic and Morse, 1999) Michael Faraday introduced the concept of induction as early as 1830 , stating that when a magnetic field flux is crosses by flow ions or a conductive material, electrical current is induced. Although magnetic field applications were rapidly pursued in order to prove Faraday's claim, attention by researchers and industrialists worldwide was still lacking (Zaidi et al., 2014). Some of the earlier studies showed that, when water is exposed to a magnetic field, the magnetization of water changes its properties including optics, electromagnetism, thermodynamics and mechanics, affecting the dielectric constant, viscosity, surface tension, freezing and boiling points and electric conductivity. Thus, magnetized water has extensive applications in industry, agriculture and medicine (Teixeira da Silva and Dobránszki, 2016). Claims have been made that magnetic fields change the physiochemical properties of water, or prepared laboratory solutions (Hozayn et al., 2016).

Salinity is aproblem in arid and semiarid regions, such as Egypt. About $33 \%$ of the cultivated land, in Egypt are saline. Such salinity is mainly due to low precipitation ( $<25 \mathrm{~mm}$ annual rainfall), high temperature, high surface evaporation (1500- $2400 \mathrm{~mm} / \mathrm{year}$ ), poor drainage irrigation with low quality and high water table Salt stress generally leads to a reduction in crop groth and yield (Parida and Das, 2005). Irrigated agriculture depends on adequate, high- 
quality water supplies. As the level of salt increases in irrigation under the quality of water for plant growth decreases. All irrigation waters contain some salt. In many areas, good quality (low salt and low sodium) water is not available for irrigation; consequently waters containing high levels of salt must be used.

Nitrogen is an essential macronutrient for plants. The increasingly severe environmental problems caused by $\mathrm{N}$ fertilizer application urge alleviation of $\mathrm{N}$ fertilizer dependence in fertilization.

Barley is one of the most important cereal crops in Egypt. it occupied a very important position in the Egyptian cropping system for its moderate salt tolerance, and ability to grow over a wide range of environmental stresses (Abd ElHady, 2007). It can tolerate chemical pollutants and give an economic yield under adverse conditions (Ayman, 2015). is mainly used for malting and subsequent beer brewing (Gupta et al., 2010). Low protein content (9.5-11.5\%) and explicit limits for contents of microorganisms and toxins are desired (FAO, 2009). For this reason, investigations on the relationship of $\mathrm{N}$ input with pathogen contamination are highly relevant to secure product quality.

The presentstudy aims at assessing (i) study the effect of salinity on the plant. (ii) the effect of the magnetized to reduce salinity. (iii) hazards transportation of ${ }^{15} \mathrm{~N}$ by plant parts. (iv) the effect of water magnetization on $\mathrm{N}$ uptake by plant.

\section{MATERIALS AND METHODS}

The experiment was conducted at Soil and Water Research Department Greenhouse, Nuclear research Center, Atomic Energy Authority, Abou-Zaabal, Egypt

The soil used in the study was sand. The experimental design was a split-split plot design involves $\mathbf{3}$ factors with three replicates. The factors were as follows:

Factor M: Two magnetized water treatments as follows:

(i) Non magnetized water $\left(M_{0}\right)$ and (ii) magnetized water $\left(M_{1}\right)$

Factor S: Four salinity stress treatments as follows:

(i) Without salinity stress $\left(S_{0}\right)$, (ii) water of $3 \mathrm{dS} \mathrm{m}^{-1}\left(\mathrm{~S}_{1}\right)$, (iii) water of $6 \mathrm{dS} \mathrm{m}^{-1}\left(\mathrm{~S}_{2}\right)$ and (iv) water of $9 \mathrm{dS} \mathrm{m}^{-1}\left(\mathrm{~S}_{3}\right)$.

Factor N: FiveN fertilization treatments \% of100 $\mathrm{mgNkg}^{-1}$ as follows:

(i) without $\mathrm{N}$ fertilization ( $\mathrm{N}_{0}$ ), (ii) $25 \mathrm{mgN} \mathrm{kg}$ $\left(\mathrm{N}_{1}\right)$ (iii) $50 \mathrm{mgNkg}$ from the recommended rate $\left(\mathrm{N}_{2}\right)$, (iv) $75 \mathrm{mgNkg}$ from the recommended rate $\left(\mathrm{N}_{3}\right)$ and $(\mathrm{v}) 100 \%$ from the recommended rate $\left(\mathrm{N}_{4}\right)$.

Nitrogen-fertilizer was applied and thoroughly mixed with soil in the pots experiment in the form of ${ }^{15} \mathrm{~N}$-Labeled ammonium sulfate with $2 \%{ }^{15} \mathrm{~N}$ atom excess at four weeks after seeding.

PVC pots with dimensions of $25 \mathrm{~cm}$ diameter and capacity of $10 \mathrm{~kg} \mathrm{pot}^{-1}$ were used in the study.

The soil was air-dried, crushed, sieved throw $0.5 \mathrm{~cm}$ sieve. Data of physical and chemical properties of the soil used in the study are shown in Table 1.

Barly (Hordum Vulgare) provided by Field Crops Research Institute was seeded at 5 seeds per pot. The saline water: wer sea water were sea water mixed with fresh water magnetization was with power of $50 \mathrm{~m}$ Tesla. The plants were irrigated during the growth season. Methods of analysis: Chemical and physical analysis of soil was carried out according to Carter and Gregorish (2008), Soltanpour (1985) and Estefan et al. (2013). The ${ }^{15} \mathrm{~N} /{ }^{14} \mathrm{~N}$ ratio was determined by emission spectrometry ${ }^{15} \mathrm{~N}$-analyzer (Model NOI-6PC) following the description of IAEA (2001). 
Table 1: Main properties of soil of the experimental field of the current study.

\begin{tabular}{|c|c|c|c|c|c|c|}
\hline$\underset{(1: 2.5)}{\text { pH }}$ & $\begin{array}{l}\text { EC 'pe'* } \\
\text { (dS m-1) }\end{array}$ & $\begin{array}{l}\mathrm{CaCO}_{3} \\
\left(\mathrm{~g} \mathrm{~kg}^{-1}\right)\end{array}$ & $\begin{array}{c}\text { Organic matter } \\
\qquad\left(\mathrm{gkg}^{-1}\right)\end{array}$ & \multicolumn{3}{|c|}{ Saturation \% (SP) } \\
\hline 7.23 & 0.37 & 0.0 & 0.3 & \multicolumn{3}{|c|}{12.47} \\
\hline \multicolumn{7}{|c|}{ Soluble lons $\left(\mathrm{mmol}_{\mathrm{c}} \mathrm{L}^{-1}\right)$} \\
\hline $\mathrm{Na}^{+}$ & \multicolumn{2}{|c|}{0.32} & $\mathrm{CO}_{3}{ }^{2-}$ & \multicolumn{3}{|c|}{0.00} \\
\hline $\mathrm{K}^{+}$ & \multicolumn{2}{|c|}{0.09} & $\mathrm{HCO}^{3-}$ & \multicolumn{3}{|c|}{0.88} \\
\hline $\mathrm{Ca}^{2+}$ & \multicolumn{2}{|c|}{1.20} & $\mathrm{Cl}^{-}$ & \multicolumn{3}{|c|}{1.25} \\
\hline $\mathbf{M g}^{2+}$ & \multicolumn{2}{|c|}{1.00} & $\mathrm{SO}_{4}^{2-}$ & \multicolumn{3}{|c|}{0.53} \\
\hline \multicolumn{7}{|c|}{ Available nutrients ${ }^{*}\left(\mathrm{mg} \mathrm{kg}^{-1}\right)$} \\
\hline $\mathbf{N}$ & $\mathbf{P}$ & K & $\mathrm{Fe}$ & Mn & $\mathrm{Zn}$ & $\mathrm{Cu}$ \\
\hline 5.0 & 2.0 & 2.2 & 25.8 & 0.5 & 1.4 & 1.4 \\
\hline \multicolumn{7}{|c|}{ Total nutrients $\left(\mathbf{g ~ k g}^{-1}\right)$} \\
\hline $\mathbf{N}$ & $\mathbf{P}$ & K & $\mathrm{Fe}$ & Mn & $\mathrm{Zn}$ & $\mathrm{Cu}$ \\
\hline 0.30 & 0.04 & 1.00 & 2.20 & 0.01 & 0.10 & 0.20 \\
\hline \multicolumn{7}{|c|}{ Particle size distribution (\%) } \\
\hline \multicolumn{2}{|c|}{ Sand } & \multicolumn{2}{|r|}{ Silt } & \multicolumn{2}{|c|}{ Clay } & Texture \\
\hline \multicolumn{2}{|c|}{98.0} & & 2.0 & \multicolumn{2}{|c|}{0.0} & Sand \\
\hline
\end{tabular}

*Extracts of: $\mathrm{KCl}$ for $\mathrm{N}, \mathrm{NH}_{4} \mathrm{HCO}_{3}$-DTPA for $\mathrm{P}, \mathrm{K}, \mathrm{Fe}, \mathrm{Mn}, \mathrm{Zn}$ and $\mathrm{Cu}$; Pe: paste extract

\section{RESULTS AND DISCUSSION}

Straw dry matter yield:

The highest straw dry matter yield was $26.40 \mathrm{~g} \mathrm{pot}^{-1}\left(\mathrm{M}_{1} \mathrm{~S}_{0} \mathrm{~N}_{4}\right)$ with on increases averaging $149.1 \%$. The lowest straw dry matter yield was $10.60 \mathrm{~g} \mathrm{pot}^{-1}$ given by $\mathrm{M}_{0} \mathrm{~S}_{3} \mathrm{~N}_{0}$. (Table 2). The low Yield was due to salinity stress. Plants were not able to absorb nitrogen from the soil because of salinity stress. The main effect of magnetization shows a $M_{1}>M_{0}$ with an increase averaging $22.9 \%$ due to $M_{1}$ but there was an interaction caused by salinity and $N$ fertilization. Under conditions of highest $\mathbf{N}$ the magnetized were passed the non magnetized alighty under conditions of S2 salinity level the magnetized did not aurpass the non magnetized.
The main effect of salinity shows a treated of $S_{0}>S_{2}>S_{3}>S_{1}$ with an a decreases averaging $10.8,0.3$ and $14.5 \%$ due to $S_{1}, S_{2}$ and $S_{3}$ respectively but there was an interaction caused by magnetization and $\mathbf{N}$ fertilization. Under conditions of non-magnetized treatment the patern was $S_{2}>S_{3}>S_{0}>S_{1}$ but under conditions of the magnetized the patern was $S_{0}>S_{3}>S_{1}>S_{2}$.

The $\mathbf{N}$ fertilization main effect shows a pattern of $\mathrm{N} 4>\mathrm{N} 3>\mathrm{N} 2>\mathrm{N} 1>\mathrm{N} 0$ with increases averaging 11.5, 32.2, 42.9 and $48.8 \%$ due to N4, N3, N2 and N1 respectively there was an interaction caused by magnetization under no magnetization both N3 and N4 were not different from each other and the the pattern was $\mathrm{N} 4=\mathrm{N} 3>\mathrm{N}_{2}>\mathrm{N}_{1}>\mathrm{N}_{\mathbf{0}}$. 
Table 2: Effect of nitrogen fertilizer rate and irrigated with magnetized and non-magnetized saline water on straw dry matter yield $\left(\mathrm{g} \mathrm{pot}^{-1}\right)$.

\begin{tabular}{|c|c|c|c|c|c|c|c|}
\hline \multirow{2}{*}{$\begin{array}{l}\text { Magnetization } \\
\text { (M) }\end{array}$} & \multirow{2}{*}{$\begin{array}{l}\text { Salinity } \\
\text { (S) }\end{array}$} & \multicolumn{5}{|c|}{ Nitrogen fertilization (N) } & \multirow{2}{*}{ mean } \\
\hline & & $\mathrm{N}_{0}$ & $\mathrm{~N}_{1}$ & $\mathbf{N}_{2}$ & $\mathbf{N}_{3}$ & $\mathbf{N}_{4}$ & \\
\hline \multirow{5}{*}{ Non Magnetized } & $\overline{S_{0}}$ & 10.80 & 12.57 & 12.46 & 14.21 & 23.01 & 114.61 \\
\hline & $S_{1}$ & 11.98 & 13.86 & 13.92 & 16.38 & 13.00 & 13.82 \\
\hline & $\mathrm{S}_{2}$ & 14.70 & 14.62 & 18.61 & 19.98 & 22.75 & 18.13 \\
\hline & $\mathrm{S}_{3}$ & 10.60 & 13.24 & 16.74 & 17.55 & 18.75 & 15.37 \\
\hline & mean & 12.01 & 13.57 & 15.43 & 17.03 & 19.38 & 15.48 \\
\hline \multirow{5}{*}{ Magnetized } & $\mathrm{S}_{0}$ & 12.60 & 19.65 & 23.24 & 24.86 & 26.40 & 21.35 \\
\hline & $\mathrm{S}_{1}$ & 19.82 & 14.40 & 17.65 & 20.78 & 18.64 & 18.25 \\
\hline & $S_{2}$ & 14.57 & 17.11 & 19.70 & 18.16 & 19.10 & 17.72 \\
\hline & $\mathrm{S}_{3}$ & 13.66 & 15.68 & 21.34 & 23.33 & 20.02 & 18.80 \\
\hline & mean & 15.16 & 16.71 & 20.48 & 21.78 & 21.04 & 19.03 \\
\hline \multicolumn{2}{|c|}{ G. mean } & 13.58 & 15.14 & 17.95 & 19.40 & 20.21 & \\
\hline \multicolumn{8}{|c|}{ Mean of Salinity (S) } \\
\hline & $\overline{S_{0}}$ & 11.70 & 16.11 & 17.85 & 19.54 & 24.70 & 17.98 \\
\hline & $\mathrm{S}_{1}$ & 15.90 & 14.13 & 15.78 & 18.58 & 15.82 & 16.04 \\
\hline & $\mathrm{S}_{2}$ & 14.63 & 15.86 & 19.15 & 19.07 & 20.92 & 17.93 \\
\hline & $S_{3}$ & 12.12 & 14.46 & 19.04 & 20.44 & 19.38 & 17.09 \\
\hline
\end{tabular}

LSD 0.05: M: 0.3 ; S: 0.4 ; N: 0.47 ; MS: 0.6 ; MN: 0.67 ; SN: 0.95 ; MSN: 1.3

The beneficial effects of magnetic treatment have also been reported on germination percentages of lower seeds (Matwijczuk et al., 2012); maize root growth (Turker et al., 2007), element uptake by same vegetables (Maheshwari and Grewal, 2009), and yield (Selim and ElNady, 2011).

\section{Grains yield:}

The lowest grain yield was $11.68 \mathrm{~g}$ pot ${ }^{1}$ by $\mathrm{M}_{0} \mathrm{~S}_{2} \mathrm{NO}$. (Table 3). The hight grain yield was $38.80 \mathrm{~g} \mathrm{pot}^{-1}$ by $\mathrm{M}_{0} \mathrm{~S}_{2} \mathrm{~N}_{4}$ with an increase averaging $232.2 \%$.

The main effect of magnetization shows the treatment of $M_{1}>M_{0}$ with an increases averaging $13.7 \%$ due to $M_{1}$ but there was an interaction caused by salinity and $N$ fertilization. Under conditions of N0 or N1 the M1 awrpassed $\mathrm{MO}$ : under $\mathrm{N}$ treatment. Under conditions of $\mathrm{S} 2$ salinity $\mathrm{MO}$ was greeter than $\mathrm{M} 0$. The main effect of salinity shows the treatment of $S_{2}>S_{0}=S_{3}=S_{1}$ with an increase averaging
$17.0 \%$ due to $S_{2}$ and a decrease averaging 4.1 and $0.8 \%$ due to $S_{1}$ and $S_{3}$ respectively there was an interaction caused by magnetization where the pattern showed differences among all salinity levels under magnetization and $\mathbf{N}$ fertilization. Under conditions of $N_{2}, N_{3}$ and $N_{4}$ the highest grain yield was given by $S_{2}$.

The $\mathbf{N}$ fertilization main effect shows the treatment of $\mathrm{N}_{4}>\mathrm{N}_{3}>\mathrm{N}_{2}>\mathrm{N}_{1}>\mathrm{N}_{0}$ with an increases averaging 5.7, 28.7, 32.1 and $36.5 \%$ due to $N_{1}, N_{2}, N_{3}$ and $N_{4}$ There was an interaction caused by the magnetized water and salinity. Under conditions of non-magnetization the patern was $\mathrm{N}_{4}>\mathrm{N}_{2}>\mathrm{N}_{3}>\mathrm{N}_{1}>\mathrm{N}_{0}$.. Under conditions of magnetization the pattern was $\mathrm{N}_{3}>\mathrm{N}_{4}>\mathrm{N}_{2}>\mathrm{N}_{0}>\mathrm{N}_{1}$. G rain yield increased when nitrogen was added to the soil as a Fertilizer form. Studies, (Tanaka et al., 2010). Other studies studies employed magnetized water and found that it can improve water productivity and crop yield (Maheshwari and Grewal, 2009). 
Table 3: Effect of nitrogen fertilizer rate and irrigated with magnetized and non-magnetized saline water on grain dry matter yield $\left(\mathrm{g} \mathrm{pot}^{-1}\right)$.

\begin{tabular}{|c|c|c|c|c|c|c|c|}
\hline \multirow{2}{*}{$\begin{array}{l}\text { Magnetized } \\
\text { (M) }\end{array}$} & \multirow{2}{*}{$\begin{array}{l}\text { Salinity } \\
\text { (S) }\end{array}$} & \multicolumn{5}{|c|}{ Nitrogen fertilization (N) } & \multirow{2}{*}{ mean } \\
\hline & & $\mathrm{N}_{0}$ & $\mathrm{~N}_{1}$ & $\mathrm{~N}_{2}$ & $\mathrm{~N}_{3}$ & $\mathrm{~N}_{4}$ & \\
\hline \multirow{5}{*}{ Non Magnetized } & $\overline{S_{0}}$ & 14.64 & 15.18 & 14.02 & 17.82 & 28.55 & 18.05 \\
\hline & $S_{1}$ & 12.55 & 12.62 & 18.16 & 15.78 & 18.70 & 15.56 \\
\hline & $S_{2}$ & 11.68 & 20.90 & 31.57 & 26.03 & 38.80 & 23.80 \\
\hline & $S_{3}$ & 12.43 & 19.63 & 20.02 & 21.29 & 14.50 & 17.57 \\
\hline & mean & 12.82 & 17.08 & 20.96 & 20.23 & 22.63 & $\overline{18.74}$ \\
\hline \multirow{5}{*}{ Magnetized } & $\overline{\mathrm{S}_{0}}$ & 14.10 & 22.25 & 24.40 & 21.21 & 22.26 & 20.84 \\
\hline & $\mathrm{S}_{1}$ & 27.66 & 18.06 & 18.76 & 22.34 & 21.86 & 21.74 \\
\hline & $S_{2}$ & 20.85 & 15.98 & 22.17 & 24.95 & 24.55 & 21.70 \\
\hline & $\mathbf{S}_{3}$ & 18.95 & 15.81 & 21.92 & 26.15 & 22.21 & 21.01 \\
\hline & mean & 20.40 & 18.02 & 21.81 & 23.66 & 22.72 & 21.32 \\
\hline \multicolumn{2}{|c|}{ G. mean } & 16.61 & 17.55 & 21.38 & 21.95 & 22.68 & \\
\hline \multicolumn{8}{|c|}{ Mean of Salinity (S) } \\
\hline & $S_{0}$ & 14.37 & 18.71 & 19.23 & 19.52 & 25.40 & 19.45 \\
\hline & $S_{1}$ & 20.10 & 15.34 & 18.46 & 19.06 & 20.28 & 18.65 \\
\hline & $S_{2}$ & 16.27 & 18.43 & 26.87 & 25.50 & 26.67 & 22.75 \\
\hline & $S_{3}$ & 15.70 & 17.72 & 20.97 & 23.72 & 18.35 & 19.29 \\
\hline
\end{tabular}

\section{$\mathbf{N}$ uptake in straw:}

The lowest $\mathrm{N}$ uptake in straw was given by the untreated treatment $\left(\mathrm{M}_{0} \mathrm{~S}_{0} \mathrm{~N}_{0}\right)$ (Table 4).. The highest straw $\mathrm{N}$ uptake of 197.9 was by M1N0S4 with increase of $343.7 \%$. (Table 4)

The main effect of magnetization shows the $M_{0}>M_{1}$ with a decrease $0.22 \%$ due to M1 but there was an interaction caused by salinity. Under conditions s 0 or s1 the pattern was $m 1>M 0$, but under conditions of other salinity leavels it was $\mathrm{M}_{1}<\mathrm{M}_{0}$. Under conditions of $\mathrm{NO}, \mathrm{N} 1$.

The main effect of salinity shows a pattern of $S_{2}>S_{0}>S_{1}>S_{3}$ with an increase about $17.7 \%$ due to $S_{2}$ and decreases averaging 11.7 and $25.1 \%$ due to $S_{1}$ and $\mathrm{S}_{3}$ respectively there was an interaction caused by magnetization and $\mathrm{N}$ fertilization. Under conditions of nomagnetization the pattern was $S_{2}>S_{3}>S_{1}>S_{0}$, but under conditions of magnetization the pattern was $S_{0}>S_{2}>S_{1}>S_{3}$. Under conditions of any N1 or N3 rate the pattern agrees with that of the main effect under other $N$ treatments the pattern disagreed that of the main treatment.

The $\mathbf{N}$ fertilization main effect shows the treatment of $\mathrm{N}_{3}>\mathrm{N}_{4}>\mathrm{N}_{2}>\mathrm{N}_{1}>\mathrm{N}_{0}$ with an increases averaging 18.7, 31.6, 47.2 and $44.9 \%$ due to $\mathrm{N}_{1}, \mathrm{~N}_{2}, \mathrm{~N}_{3}$ and $\mathrm{N}_{4}$ respectively There was an interaction caused by the magnetized water and salinity under conditions of nonmagnetization the pattern was $\mathrm{N}_{4}>\mathrm{N}_{3}>\mathrm{N}_{2}>\mathrm{N}_{1}>\mathrm{N}_{0}$ respectively. Under conditions of magnetized the pattern was $N_{3}>N_{4}>N_{1}>N_{2}>N_{0}$. Under conditions of any salinity stress treatment the pattern was disagree with the main effect.

Magnetization gave positive effect against (Maheshwari and Grewal, 2009), and caused mobility of nutrients from fertilizers (Hozayn and Abdul Qados, 2010), water holding capacity of soil (AlKhazan et al., 2011); and decreased soil pH. (Chang and Weng, 2006). 
Table 4: Effect of nitrogen fertilizer rate and irrigated with magnetized and non-magnetized saline water on $\mathrm{N}$ uptake in straw dry matter yield $\mathrm{g} \mathrm{pot}^{-1}$.

\begin{tabular}{|c|c|c|c|c|c|c|c|}
\hline \multirow{2}{*}{$\begin{array}{l}\text { Magnetized } \\
\text { (M) }\end{array}$} & \multirow{2}{*}{$\begin{array}{l}\text { Salinity } \\
\text { (S) }\end{array}$} & \multicolumn{5}{|c|}{ Nitrogen fertilization (N) } & \multirow{2}{*}{ Mean } \\
\hline & & $\mathrm{N}_{0}$ & $N_{1}$ & $\mathbf{N}_{2}$ & $\mathbf{N}_{3}$ & $\mathbf{N}_{4}$ & \\
\hline \multirow{5}{*}{$\begin{array}{c}\text { Non } \\
\text { Magnetized }\end{array}$} & $S_{0}$ & 44.6 & 59.1 & 77.5 & 60.9 & 148.8 & 78.2 \\
\hline & $S_{1}$ & 67.7 & 88.2 & 73.5 & 86.8 & 77.1 & 78.6 \\
\hline & $\mathrm{S}_{2}$ & 97.3 & 88.5 & 146.5 & 162.4 & 127.4 & 124.4 \\
\hline & $\mathbf{S}_{3}$ & 53.2 & 73.2 & 96.6 & 96.7 & 79.5 & 79.8 \\
\hline & mean & 65.7 & 77.2 & 98.5 & 101.6 & 108.2 & 90.3 \\
\hline \multirow{5}{*}{ Magnetized } & $S_{0}$ & 75.7 & 97.1 & 93.5 & 136.5 & 197.9 & 108.1 \\
\hline & $\mathbf{S}_{1}$ & 93.6 & 94.4 & 76.5 & 93.2 & 83.5 & 88.2 \\
\hline & $S_{2}$ & 73.8 & 111.9 & 94.5 & 101.7 & 93.6 & 95.1 \\
\hline & $\mathrm{S}_{3}$ & 56.1 & 53.7 & 81.1 & 88.9 & 65.8 & 69.1 \\
\hline & mean & 74.8 & 89.3 & 86.4 & 105.0 & 95.2 & 90.1 \\
\hline \multicolumn{2}{|c|}{ G. mean } & 70.2 & 83.3 & 92.4 & 103.3 & 101.7 & \\
\hline \multicolumn{8}{|c|}{ Mean of Salinity (S) } \\
\hline & $S_{0}$ & 60.2 & 78.1 & 85.5 & 98.7 & 143.3 & 93.2 \\
\hline & $S_{1}$ & 80.7 & 91.3 & 75.0 & 90.0 & 80.3 & 83.4 \\
\hline & $S_{2}$ & 85.6 & 100.2 & 120.5 & 132.0 & 110.5 & 109.7 \\
\hline & $\mathrm{S}_{3}$ & 54.6 & 63.4 & 88.9 & 92.8 & 72.6 & 74.5 \\
\hline
\end{tabular}

LSD 0.05: M: 0.98 ; S: 1.4 ; N: 1.56 ;MS: 1.97 ;MN:2.2 ; SN: 3.27 ;MSN: 4.4

$\mathrm{N}$ uptake in grains:

Data in Table 5 Show that the lowest $\mathbf{N}$ uptake of $117.9 \mathrm{~g} \mathrm{pot}^{-1}$ by $\mathrm{M}_{0} \mathrm{~S}_{1} \mathrm{~N}_{3}$. The highest grains $\mathrm{N}$ uptake was $372.9 \mathrm{~g} \mathrm{pot}^{-1}$ in grains was by $M_{0} S_{2} N_{2}$ with an increase about $216.3 \%$. This high $\mathrm{N}$ uptake was given because of the medium $\mathbf{N}$ fertilizer. The main effect of magnetization shows a pattern of $M_{1}>M_{0}$ with a increases about $20.2 \%$ due to $M_{1}$ but there was an interaction caused by salinity and $N$ fertilization. Under conditions of N4 the difference between M1 and M0was very slight, but under conditions of other $\mathrm{N}$ treatments M1 surpased M0 concederably. Under conditions of S0 and $S 2$ the pattern was $M_{0}>M_{1}$.. The main effect of salinity shows a pattern of $S_{2}>S_{3}>S_{0}>S 1$ with an increase about 141.1, 2.7\% due to
$S_{2}$ and $S 3$ and a decrease about $11.0 \%$ due to $S_{1}$ There was an interaction caused by the magnetization fertilization. under no magnetization the pattern was $S_{2}>S_{3}>S_{0}>S 1$, Under conditions of N4 the pattern was $\mathrm{N} 1>\mathrm{N} 2>\mathrm{N} 0>\mathrm{N} 3$ under N0 the pattern was N1> N2 . N3> N0.The N fertilization main effect shows the treatment of $\mathrm{N}_{3}>\mathrm{N}_{4}>\mathrm{N}_{2}>\mathrm{N}_{0}>\mathrm{N}_{1}$ with an increases averaging 28.1, 41.2 and $29.6 \%$ due to $N_{2}, N_{3}$ and $N_{4}$ respectively and a decreases about $4.9 \%$ due to $N_{1}$ under no magnetization the pattern was $\mathrm{N}_{4}>\mathrm{N}_{3}>\mathrm{N}_{2}>\mathrm{N}_{1}>\mathrm{N}_{\mathbf{0}}$. Under magnetization the pattern was $\mathrm{N}_{3}>\mathrm{N}_{2}>\mathrm{N}_{4}>\mathrm{N}_{0}>\mathrm{N}_{1}$. Under conditions of S3 the pattern was N3> N2 > $\mathrm{N} 4>\mathrm{N} 1>\mathrm{N} 0$. Under $\mathrm{S3}$ it wasN3 $>\mathrm{N} 2>\mathrm{N} 1>\mathrm{N} 0$. 
Menoufia J. Soil Sci.,Vol. 5 February (2020): 19 - 31

Table 5: Effect of nitrogen fertilizer rate and irrigated with magnetized and non-magnetized saline water on $\mathrm{N}$ uptake in grains $\left(\mathrm{mg} \mathrm{pot}^{-1}\right)$.

\begin{tabular}{|c|c|c|c|c|c|c|c|}
\hline \multirow{2}{*}{$\begin{array}{l}\text { Magnetized } \\
\text { (M) }\end{array}$} & \multirow{2}{*}{$\begin{array}{c}\text { Salinity } \\
\text { (S) }\end{array}$} & \multicolumn{5}{|c|}{ Nitrogen fertilization (N) } & \multirow{2}{*}{ mean } \\
\hline & & $\mathrm{N}_{0}$ & $\mathbf{N}_{1}$ & $\mathbf{N}_{2}$ & $\mathbf{N}_{3}$ & $\mathrm{~N}_{4}$ & \\
\hline \multirow{5}{*}{$\begin{array}{c}\text { Non } \\
\text { Magnetized }\end{array}$} & $\mathrm{S}_{0}$ & 163.5 & 125.5 & 196.1 & 237.3 & 364.5 & 217.4 \\
\hline & $\mathbf{S}_{1}$ & 193.8 & 139.9 & 195.3 & 117.9 & 200.1 & 169.4 \\
\hline & $\mathbf{S}_{2}$ & 161.1 & 216.7 & 372.9 & 372.1 & 311.1 & 286.8 \\
\hline & $\mathrm{S}_{3}$ & 139.0 & 246.6 & 253.2 & 310.5 & 175.3 & 224.9 \\
\hline & mean & 164.3 & 182.2 & 254.3 & 259.4 & 262.7 & 224.6 \\
\hline \multirow{5}{*}{ Magnetized } & $\mathbf{S}_{0}$ & 173.7 & 269.3 & 356.2 & 261.1 & 267.0 & 265.4 \\
\hline & $\mathbf{S}_{1}$ & 320.5 & 182.5 & 187.7 & 338.1 & 272.3 & 260.2 \\
\hline & $\mathbf{S}_{2}$ & 274.8 & 216.0 & 265.0 & 357.4 & 303.4 & 283.3 \\
\hline & $\mathrm{S}_{3}$ & 238.3 & 190.1 & 305.6 & 356.5 & 264.6 & 271 \\
\hline & mean & 251.8 & 214.5 & 278.6 & 328.3 & 276.8 & 270.0 \\
\hline \multicolumn{2}{|c|}{ G. mean } & 208.1 & 198.3 & 266.5 & 293.9 & 269.8 & \\
\hline \multicolumn{8}{|c|}{ Mean of Salinity (S) } \\
\hline & $S_{0}$ & 168.6 & 197.4 & 276.1 & 249.2 & 315.7 & 241.4 \\
\hline & $S_{1}$ & 257.1 & 161.2 & 191.5 & 228.0 & 336.2 & 214.8 \\
\hline & $S_{2}$ & 217.9 & 216.3 & 318.9 & 364.8 & 307.2 & 285.0 \\
\hline & $\mathrm{S}_{3}$ & 188.6 & 218.4 & 279.4 & 333.5 & 219.9 & 247.9 \\
\hline
\end{tabular}

LSD 0.05: M: 2.6 ; S: 3.7 ; N: $4.1 \quad$; MS: 5.2 ; MN: $5.8 \quad$; SN: 8.26 ; MSN: 11.7

Na uptake in straw: (Table 6)

The lowest $\mathrm{Na}$ uptake in straw was $114.3 \mathrm{~g} \mathrm{pot}^{-1}$ by $\mathrm{M}_{0} \mathrm{~S}_{0} \mathrm{~N}_{0}$. The highest $\mathrm{Na}$ uptake in straw $580.1 \mathrm{~g} \mathrm{pot}^{-1}$ by $\mathrm{M}_{1} \mathrm{~S}_{0} \mathrm{~N}_{4}$ with increase of $407.5 \%$. The main effect of magnetization shows $M_{1}>M_{0}$ with an increase $62.1 \%$ due to $M_{1}$. Under conditions of $\mathrm{N} 4$ the increase of M1 over MO was not very high. The main effect of salinity shows the treatment of $S_{3}>S_{2}>S_{0}>S_{1}$ with an increases averaging 5.6 and $13.6 \%$ due to $S_{2}$ and $S_{3}$ and respectively and a decrease $8.9 \%$ due to $S_{1}$. Under conditions of no magnetization the pattern was $S_{2}>S_{3}>S_{1}>S_{0}$, Under conditions of magnetization the pattern was $S_{3}>S_{0}>S_{1}>S_{2}$.. The $\mathbf{N}$ fertilization main effect shows the treatment of $\mathrm{N}_{4}>\mathrm{N}_{3}>\mathrm{N}_{2}>\mathrm{N}_{1}>\mathrm{N}_{0}$ with an increases averaging $10.8,42.9,44.5$ and $11.9 \%$ due to N1, N2, N3 and N4 respectively.. With condition of no-magnetization the pattern agres with the main effect. Under conditions of magnetized it was $\mathrm{N}_{4}>\mathrm{N}_{2}>\mathrm{N}_{3}>\mathrm{N}_{1}>\mathrm{N}_{\mathbf{0}}$. Under conditions ofS 3 or S1 the N3 treatment showed hight N uptake followed by N4. 
Menoufia J. Soil Sci.,Vol. 5 February (2020): 19 - 31

Table 6: Effect of nitrogen fertilizer rate and irrigated with magnetized and non-magnetized saline water on Na uptake in strawm $\mathrm{g} \mathrm{pot}^{-1}$.

\begin{tabular}{|c|c|c|c|c|c|c|c|}
\hline \multirow{2}{*}{$\begin{array}{c}\text { Magnetized } \\
\text { (M) }\end{array}$} & \multirow{2}{*}{$\begin{array}{l}\text { Salinity } \\
\text { (S) }\end{array}$} & \multicolumn{5}{|c|}{ Nitrogen fertilization (N) } & \multirow{2}{*}{ mean } \\
\hline & & $\mathbf{N}_{0}$ & $\mathbf{N}_{1}$ & $\mathbf{N}_{2}$ & $\mathbf{N}_{3}$ & $\mathbf{N}_{4}$ & \\
\hline \multirow{5}{*}{$\begin{array}{c}\text { Non } \\
\text { Magnetized }\end{array}$} & $\mathbf{S}_{0}$ & 114.3 & 181.2 & 188.9 & 191.9 & 304.2 & 196.1 \\
\hline & $\mathbf{S}_{1}$ & 149.7 & 182.7 & 189.8 & 270.5 & 172.2 & 193.0 \\
\hline & $\mathrm{S}_{2}$ & 266.1 & 263.2 & 317.2 & 336.1 & 383.5 & 313.2 \\
\hline & $\mathrm{S}_{3}$ & 177.9 & 209.4 & 371.6 & 317.9 & 305.6 & 276.5 \\
\hline & mean & 177.0 & 209.1 & 266.9 & 279.1 & 291.4 & 244.7 \\
\hline \multirow{5}{*}{ Magnetized } & $\mathrm{S}_{0}$ & 223.9 & 414.3 & 491.4 & 436.1 & 580.1 & 429.1 \\
\hline & $S_{1}$ & 384.8 & 287.6 & 362.8 & 439.3 & 407.7 & 376.4 \\
\hline & $\mathrm{S}_{2}$ & 333.9 & 275.7 & 265.6 & 351.0 & 409.3 & 347.1 \\
\hline & $\mathrm{S}_{3}$ & 326.0 & 337.2 & 536.0 & 512.9 & 457.7 & 433.9 \\
\hline & mean & 317.1 & 328.7 & 438.9 & 434.8 & 463.7 & 396.6 \\
\hline \multicolumn{2}{|c|}{ G. mean } & 247.0 & 268.9 & 352.9 & 356.9 & 377.5 & \\
\hline \multicolumn{8}{|c|}{ Mean of Salinity (S) } \\
\hline & $S_{0}$ & 169.1 & 197.7 & 340.2 & 314.0 & 442.1 & 312.6 \\
\hline & $S_{1}$ & 267.2 & 235.1 & 276.3 & 354.9 & 289.9 & 284.7 \\
\hline & $S_{2}$ & 300.0 & 269.4 & 341.4 & 343.6 & 396.4 & 330.1 \\
\hline & $\mathrm{S}_{3}$ & 251.9 & 273.3 & 253.8 & 415.4 & 381.6 & 355.2 \\
\hline
\end{tabular}

LSD 0.05: M: 2.4 ; S: 3.4 ; N: 3.8 ; MS: 4.8 ; MN: 5.3 ; SN: 7.5 ; MSN:10.7

Na uptake in grains:

The lowest $\mathrm{Na}$ uptake in grains was $11.42 \mathrm{~g} \mathrm{pot}^{-1}$ caused by $\mathrm{M}_{0} \mathrm{~S}_{2} \mathrm{~N}_{0}$. The highest $\mathrm{Na}$ uptake $30.44 \mathrm{~g} \mathrm{pot}^{-1}$ was by $\mathrm{M}_{1} \mathrm{~S}_{2} \mathrm{~N}_{2}$ with an increase of $166.5 \%$. (Table 7). The main effect of magnetization shows a pattern of $M_{1}>M_{0}$ with an increase of $13.1 \%$ due to $\mathrm{M}_{1}$ under Conditions of $\mathrm{N} 4$ there was no difference between MO and M1 Under conditions of S2 the pattern was M0>M1 The main effect of salinity shows $S_{2}>S_{0}>S_{3}>S_{1}$ with an increase of about $18.0 \%$ due to $S_{2}$ and decreases averaging $5.4,1.8 \%$ due to $S_{1}, S_{3}$ respectively under no magnetization the pattern agres with the main effect, but under magnetization it was $\mathrm{S}_{1}>\mathrm{S}_{2}>\mathrm{S}_{3}>\mathrm{S}_{0}$. Under $\mathrm{N} 4$ it was $\mathrm{S} 2>\mathrm{S} 0>\mathrm{S}>\mathrm{S} 3$.

The $\mathbf{N}$ fertilization main effect shows a pattern of $\mathrm{N}_{4}>\mathrm{N}_{2}>\mathrm{N}_{3}>\mathrm{N}_{1}>\mathrm{N}_{0}$ with increase averaging 7.0, 129.3, 35.3 and $39.0 \%$ due to $N_{1}, N_{2}, N_{3}$ and $N_{4}$ respectively.. Under conditions of no magnetization the pattern was $\mathrm{N}_{4}>\mathrm{N}_{3}>\mathrm{N}_{2}>\mathrm{N}_{1}>\mathrm{N}_{0}$. Under conditions of magnetization it was $\mathrm{N}_{3}>\mathrm{N}_{4}>\mathrm{N}_{2}>\mathrm{N}_{\mathbf{0}}>\mathrm{N}_{1}$. Under conditions $\mathrm{S} 1$ the pattern was $\mathrm{N} 4>\mathrm{N} 0>\mathrm{N} 3>\mathrm{N} 2>\mathrm{N} 1$. 
Menoufia J. Soil Sci., Vol. 5 February (2020): 19 - 31

Table 7: Effect of nitrogen fertilizer rate and irrigated with magnetized and non-magnetized saline water on Na uptake in grainsm $\mathrm{g} \mathrm{pot}^{-1}$.

\begin{tabular}{|c|c|c|c|c|c|c|c|}
\hline \multirow{2}{*}{$\begin{array}{l}\text { Magnetized } \\
\text { (M) }\end{array}$} & \multirow{2}{*}{$\begin{array}{l}\text { Salinity } \\
\text { (S) }\end{array}$} & \multicolumn{5}{|c|}{ Nitrogen fertilization (N) } & \multirow{2}{*}{ mean } \\
\hline & & $\mathrm{N}_{0}$ & $N_{1}$ & $\mathrm{~N}_{2}$ & $\mathrm{~N}_{3}$ & $\mathrm{~N}_{4}$ & \\
\hline \multirow{5}{*}{$\begin{array}{c}\text { Non } \\
\text { Magnetized }\end{array}$} & $S_{0}$ & 14.37 & 15.41 & 14.37 & 17.55 & 28.55 & 18.05 \\
\hline & $\mathbf{S}_{1}$ & 11.72 & 12.37 & 18.16 & 15.57 & 18.44 & 15.25 \\
\hline & $\mathbf{S}_{2}$ & 11.42 & 20.63 & 30.44 & 30.38 & 29.62 & 24.50 \\
\hline & $\mathrm{S}_{3}$ & 12.86 & 19.26 & 20.40 & 20.63 & 14.97 & 17.62 \\
\hline & mean & 12.60 & 16.92 & 20.84 & 21.03 & 22.90 & 18.85 \\
\hline \multirow{5}{*}{ Magnetized } & $S_{0}$ & 13.97 & 22.25 & 24.40 & 21.96 & 22.80 & 21.07 \\
\hline & $S_{1}$ & 27.66 & 19.01 & 18.32 & 21.92 & 21.86 & 21.75 \\
\hline & $\mathrm{S}_{2}$ & 20.67 & 15.98 & 22.17 & 24.95 & 24.55 & 21.66 \\
\hline & $\mathrm{S}_{3}$ & 18.95 & 15.81 & 21.92 & 25.12 & 22.21 & 20.80 \\
\hline & mean & 20.31 & 18.26 & 21.70 & 23.50 & 22.85 & 21.32 \\
\hline \multicolumn{2}{|c|}{ G. mean } & 16.45 & 17.60 & 21.27 & 22.26 & 22.87 & \\
\hline \multicolumn{8}{|c|}{ Mean of Salinity (S) } \\
\hline & $S_{0}$ & 14.17 & 18.83 & 19.38 & 19.75 & 25.67 & 19.56 \\
\hline & $\mathrm{S}_{1}$ & 19.70 & 15.70 & 18.24 & 18.74 & 20.15 & 18.50 \\
\hline & $S_{2}$ & 16.05 & 18.31 & 26.30 & 27.66 & 27.08 & 23.08 \\
\hline & $S_{3}$ & 15.90 & 17.54 & 21.15 & 22.88 & 18.60 & 19.21 \\
\hline
\end{tabular}

LSD 0.05: M: 0.2 ; S: 0.27 ; N: 0.3 ; MS: 0.4 ; MN: 0.43 ; SN: 0.6 ; MSN: 0.87

Nitrogen recovery by straw (NR): $\mathrm{N}$ recovery by straw ranged from 0.11 to 7.76 $g$ pot ${ }^{-1}$ due to $M_{0} S_{0} N_{3}$ and $M_{1} S_{2} N_{1}$, respectively. (Table 8). The main effect of magnetized gave an increase due to $M_{1}$. The main effect of salinity show an increase in nitrogen recovery when the salinity was in medium rates. The main effect of $\mathbf{N}$ fertilization gave an increase in NR due to $\mathrm{N}_{1}$ followed by $\mathrm{N}_{2}$.

$\mathrm{N}$ recovery (NR) by grains ranged from 0.65 to $25.14 \mathrm{~g} \mathrm{pot}^{-1}$ due to $\mathrm{M}_{0} \mathrm{~S}_{0} \mathrm{~N}_{1}$ and $M_{1} S_{1} N_{1}$, respectively (Table 9). The main effect of magnetized gave an increase due to $M_{1}$. The main effect of salinity show an increase in NR when the salinity was high. The main effect of $\mathrm{N}$ fertilization gave an increase in NR due to $N_{2}$ followed by $N_{1}$.: Harmsen and Garabet (2003) refers to the recovery by subtraction as the "apparent $\mathrm{N}$-recovery fraction whereas that given by the ${ }^{15} \mathrm{~N}$ tracer as the ${ }^{15} \mathrm{~N}$ recovery fraction.

Nitrogen which remained in soil after harvest (NrS):

${ }^{15} \mathrm{~N}$ which remained in the soil is shown in Table 10. The values ranged from 0.13 to 0.65 due to $M_{0} S_{2} N_{1}$ and $M_{1} S_{3} N_{1}$, respectively. The main effect of magnetization shows an increase due to $\mathbf{M}_{1}$. Under conditions of magnetization and $\mathrm{N}_{4}$ there was high $\mathrm{g} \mathrm{kg}^{-1}$ soil of $\mathrm{N}$ remaining in the soil after harvest. The main effect of salinity gave a pattern of $S_{0}>S_{1}>S_{2}>S_{3}$. $N$ fertilization main effect gave high ${ }^{15} \mathrm{~N}$ in the soil under conditions of $\mathrm{N}_{4}$. 
Menoufia J. Soil Sci., Vol. 5 February (2020): 19 - 31

Table 8: Effect of nitrogen fertilizer rate and irrigated with magnetized and non-magnetized saline water on $\mathrm{N}$ recovery by straw (\%).

\begin{tabular}{|c|c|c|c|c|c|c|}
\hline \multirow{2}{*}{$\begin{array}{l}\text { Magnetized } \\
\text { (M) }\end{array}$} & \multirow{2}{*}{$\begin{array}{l}\text { Salinity } \\
\text { (S) }\end{array}$} & \multicolumn{4}{|c|}{ Nitrogen fertilization (N) } & \multirow[t]{2}{*}{ Mean } \\
\hline & & $\mathbf{N}_{1}$ & $\mathbf{N}_{2}$ & $\mathbf{N}_{3}$ & $\mathbf{N}_{4}$ & \\
\hline \multirow{5}{*}{ Non Magnetized } & $S_{0}$ & 0.26 & 0.15 & 0.11 & 0.60 & 0.28 \\
\hline & $S_{1}$ & 2.12 & 0.98 & 0.72 & 0.65 & 1.12 \\
\hline & $S_{2}$ & 3.46 & 3.65 & 0.29 & 0.34 & 1.93 \\
\hline & $S_{3}$ & 1.69 & 0.43 & 0.46 & 0.04 & 0.66 \\
\hline & mean & 1.88 & 1.30 & 0.39 & 0.41 & 1.00 \\
\hline \multirow{5}{*}{ Magnetized } & $\mathrm{S}_{0}$ & 2.42 & 0.09 & 1.70 & 4.93 & 2.28 \\
\hline & $S_{1}$ & 6.04 & 6.53 & 2.49 & 3.04 & 4.52 \\
\hline & $S_{2}$ & 7.76 & 2.28 & 0.30 & 0.17 & 3.13 \\
\hline & $\mathrm{S}_{3}$ & 5.92 & 4.47 & 0.26 & 1.55 & 3.05 \\
\hline & mean & 5.53 & 3.84 & 1.19 & 2.42 & 3.25 \\
\hline \multicolumn{2}{|c|}{ G. mean } & 3.71 & 2.57 & 0.79 & 1.41 & 2.12 \\
\hline & $S_{0}$ & 1.34 & 0.12 & 0.90 & 2.76 & 1.28 \\
\hline & $S_{1}$ & 4.08 & 3.75 & 1.60 & 1.85 & 2.82 \\
\hline & $\mathbf{S}_{2}$ & 5.61 & 3.97 & 0.30 & 0.25 & 2.53 \\
\hline & $\mathrm{S}_{3}$ & 3.81 & 2.45 & 0.36 & 0.80 & 1.85 \\
\hline
\end{tabular}

Table 9: Effect of nitrogen fertilizer rate and irrigated with magnetized and non-magnetized saline water on $\mathrm{N}$ recovery in grains (\%).

\begin{tabular}{|c|c|c|c|c|c|c|}
\hline \multirow{2}{*}{$\begin{array}{l}\text { Magnetized } \\
\text { (M) }\end{array}$} & \multirow{2}{*}{$\begin{array}{l}\text { Salinity } \\
\text { (S) }\end{array}$} & \multicolumn{4}{|c|}{ Nitrogen fertilization (N) } & \multirow[t]{2}{*}{ Mean } \\
\hline & & $\mathbf{N}_{1}$ & $\mathbf{N}_{2}$ & $\mathrm{~N}_{3}$ & $\mathbf{N}_{4}$ & \\
\hline \multirow{5}{*}{ Non Magnetized } & $\mathrm{S}_{0}$ & 0.65 & 9.15 & 4.57 & 8.91 & 5.80 \\
\hline & $S_{1}$ & 6.84 & 9.11 & 2.62 & 2.89 & 5.37 \\
\hline & $S_{2}$ & 20.23 & 20.72 & 18.19 & 14.52 & 18.41 \\
\hline & $\mathrm{S}_{3}$ & 24.11 & 16.88 & 14.72 & 2.34 & 14.51 \\
\hline & mean & 12.93 & 13.97 & 10.03 & 7.16 & 11.02 \\
\hline \multirow{5}{*}{ Magnetized } & $\mathrm{S}_{0}$ & 14.36 & 26.12 & 8.51 & 6.23 & 13.81 \\
\hline & $S_{1}$ & 25.14 & 9.18 & 16.53 & 3.33 & 13.54 \\
\hline & $\mathrm{S}_{2}$ & 17.28 & 10.60 & 5.82 & 4.05 & 9.44 \\
\hline & $\mathrm{S}_{3}$ & 8.45 & 39.39 & 15.84 & 8.82 & 18.13 \\
\hline & mean & 16.31 & 21.32 & 11.68 & 5.61 & 13.73 \\
\hline \multicolumn{2}{|c|}{ G. mean } & 14.62 & 17.64 & 10.85 & 6.38 & 12.38 \\
\hline & $\overline{S_{0}}$ & 7.46 & 17.64 & 6.54 & 7.57 & 9.80 \\
\hline & $\mathrm{S}_{1}$ & 15.99 & 9.15 & 9.57 & 3.11 & 9.46 \\
\hline & $\mathrm{S}_{2}$ & 18.45 & 15.66 & 12.01 & 9.28 & 13.93 \\
\hline & $\mathrm{S}_{3}$ & 16.28 & 28.13 & 15.28 & 5.58 & 16.32 \\
\hline
\end{tabular}


Table 10: Effect of nitrogen fertilizer rate and irrigated with magnetized and nonmagnetized saline water on $\mathrm{N}$ remained in soil harvest $\left(\mathrm{g} \mathrm{kg}^{-1}\right)$.

\begin{tabular}{|c|c|c|c|c|c|c|}
\hline \multirow{2}{*}{$\begin{array}{l}\text { Magnetized } \\
\text { (M) }\end{array}$} & \multirow{2}{*}{$\begin{array}{c}\text { Salinity } \\
\text { (S) }\end{array}$} & \multicolumn{4}{|c|}{ Nitrogen fertilization (N) } & \multirow[t]{2}{*}{ Mean } \\
\hline & & $\mathbf{N}_{1}$ & $\mathbf{N}_{2}$ & $\mathbf{N}_{3}$ & $\mathbf{N}_{4}$ & \\
\hline \multirow{5}{*}{ Non Magnetized } & $S_{0}$ & 0.17 & 0.23 & 0.66 & 0.15 & 0.30 \\
\hline & $S_{1}$ & 0.28 & 0.20 & 0.15 & 0.28 & 0.23 \\
\hline & $S_{2}$ & 0.13 & 0.18 & 0.62 & 0.82 & 0.44 \\
\hline & $S_{3}$ & 0.62 & 0.10 & 0.12 & 0.25 & 0.27 \\
\hline & mean & 0.30 & 0.18 & 0.39 & 0.38 & 0.31 \\
\hline \multirow{5}{*}{ Magnetized } & $S_{0}$ & 0.46 & 0.30 & 0.55 & 0.51 & 0.46 \\
\hline & $S_{1}$ & 0.38 & 0.14 & 0.23 & 1.12 & 0.47 \\
\hline & $\mathrm{S}_{2}$ & 0.30 & 0.18 & 0.18 & 0.28 & 0.24 \\
\hline & $\mathrm{S}_{3}$ & 0.65 & 0.14 & 0.15 & 0.26 & 0.30 \\
\hline & mean & 0.45 & 0.19 & 0.28 & 0.54 & 0.36 \\
\hline \multicolumn{2}{|c|}{ G. mean } & 0.37 & 0.18 & 0.33 & 0.46 & 0.34 \\
\hline & $S_{0}$ & 0.31 & 0.27 & 0.61 & 0.33 & 0.38 \\
\hline & $\mathrm{S}_{1}$ & 0.33 & 0.17 & 0.19 & 0.70 & 0.35 \\
\hline & $S_{2}$ & 0.22 & 0.18 & 0.40 & 0.55 & 0.34 \\
\hline & $S_{3}$ & 0.63 & 0.12 & 0.13 & 0.25 & 0.29 \\
\hline
\end{tabular}

\section{REFERENCES}

Abd El-Hady, B.A. (2007). Effect of zinc application on growth and nutrient uptake of barley plant irrigated with saline water. J. Appl. Sci. Res. 3 (6): 431-436.

Al-Khazan, M., M. Batoul and N. Al-Assaf (2011). Effects of magnetized low quality water on some soil properties and plant status: chlorophyll pigments and some elements content of Jojoba (Simmondsia chinensis L.) at different growth stages. Afr. J. Environ. Sci. Technol. 5: 722-731.

Ayman, M.H.A. (2015). Assessment of water quality of wastewaters of Bahr El-Baqar, Bilbies and El-Qalyubia drains in east delta, Egypt for irrigation purposes. Egypt J. Soil Sci. Egypt J. Soil Sci. 55: 119-146.
Chang, K.T. and C.I. Weng (2006). The effect of an external magnetic field on the structure of liquid water using molecular dynamics simulation. J. App. Phys. 100: 43917-43922.

Colic, M. and D. Morse (1999). The elusive mechanism of the magnetic 'memory' of water. Coll. Surf. 154 (1-2), 167-174.

Estefan, G., R. Sommer and J. Ryan (2013). Methods of soil, plant and water analysis: a manual for the West Asia and North Africa region. Intl. Center Agric. Res. Dry Areas (ICARDA), $3^{\text {rd }}$ edition.

FAO, (2009). Agribusiness Handbook: Barley, Malt, Beer. FAO Investment Centre Division (accessed on 11.12.15.). Available at:http://www.fao.org/fileadmin/user u 
pload/tci/docs/AH3 BarleyMaltBeer.pd f.

Gupta, M., N. Abu-Ghannam and E. Gallagher (2010). Barley for brewing: characteristic changes during malting, brewing and applications of its byproducts. Compr. Rev. Food Sci. Food Saf. 9: 318-328.

Harmsen, K. and S. Garabet (2003). A comparison of the isotope-dilution and the difference method for estimating fertilizer nitrogen recovery fractions in crops. III. Experimental. Nuclear J. Appl. Sci. 51: 237-261.

Hozayn, M. and A.M.S. Abdul Qados (2010). Irrigation with magnetized water enhances growth, chemical constituent and yield of chickpea (Cicer arietinum L.). Agric. Biol. J. North Am. 1: 671-676.

Hozayn, M., M.M. Canola Abdallha, A.A. Abd El-Monem, A.A. El-Saady and M.A. Darwish (2016). Applications of magnetic technology in agriculture: a novel tool for improving crop productivity. Afr. J. Agric. Res. 11 (5): 441-449.

IAEA (2001). Training course. International Atomic Energy Agency (IAEA) No. 14, Vienna, Austria.

Maheshwari, B.L. and H.S. Grewal (2009). Magnetic treatment of irrigation water: its effects on vegetable crop yield and water productivity. Agric. Water Manage. 96: 1229-1236.

Matwijczuk, A., K. Kornarzynski and S. Pietruszewski (2012). Effect of magnetic field on seed germination and seedling growth of sunflower. Int. Agrophys. 26: 271-278.
Parida, A. K. and A. B. Das (2005). Salt tolerance and salinity effects on plants. Ecotox. Envirion. Saf. 60: 324-349.

Quan, X., Q. Qian, Z. Ye, J. Zeng, Z. Han and G. Zhang (2016). Metabolic analysis of two contrasting wild barley genotypes grown hydroponically reveals adaptive strategies in response to low nitrogen stress. Journal of plant physiology 206: 59-67.

Selim, El-Nady (2011). Physio-anatomical responses of drought stressed tomato plants to magnetic field. Acta Astron. 69: 387-396.

Soltanpour, P. N. (1985). Use of ammonium bicarbonate DTPA soil test to evaluate elemental availability and toxicity. Commun. Soil Sci. Plant Anal. 16:323-318.

Tanaka, M., P.T. Van, J.A. Teixeira da Silva and L.H. Ham (2010). Novel magnetic field system: application to micro propagation of horticultural plants. Biotech. Biotechnol. Equip. 24: 21602163.

Teixeira da Silva, J.A. and J. Dobránszki (2016). Magnetic fields: how is plant growth and development impacted? Protoplasma 253: 231-248.

Turker, M., C. Temirci, P. Battal and M.E. Erez (2007). The effects of an artificial and static magnetic field on plant growth chlorophyll and phytohormone levels in maize and sunflower plants. Phys. Ann. Rev. Bot. 46: 271-284.

Zaidi, N.M., Sohaili, Johan, Muda, Khalida, Sillanpaa and Mika (2014). Magnetic field application and its potential in water and wastewater treatment systems. Sep. Purif. Rev. 43: 206-240. 
أثر معدلات السماد النتروجيني على انتاجية الثعير المروى بالمياه الماحة الممغنة

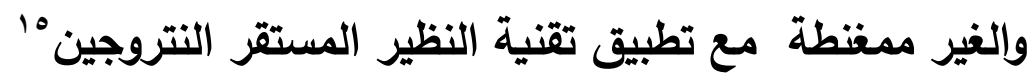

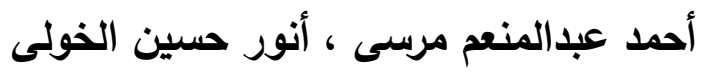

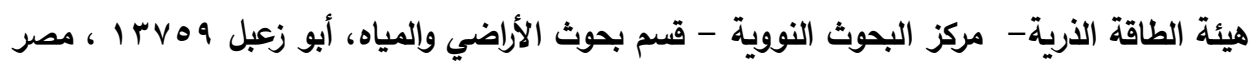

الملخص العربى

اقيمت تجربة اصص فى الصوبة الزراعية وذلك بهفف دراسة تأثير مستويات مختلفة من الملوحة على محصول الثعير

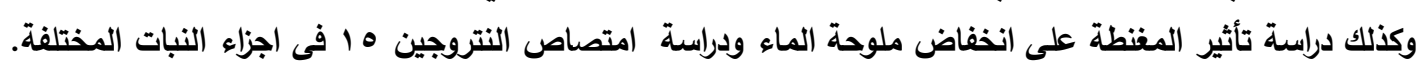

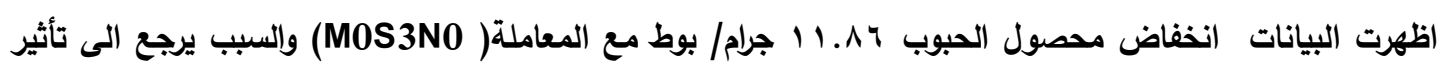
ارتفاع الملوحة وقلة اضافة النتروجين وعلى العكس ادى اضافة نفس المعاملات مع التركيز المرتفع من النتروجين الى زياده

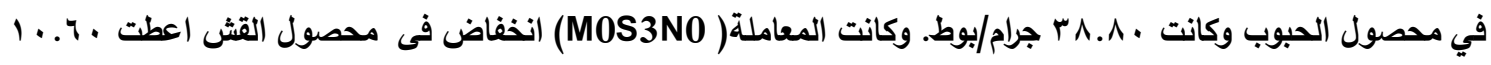

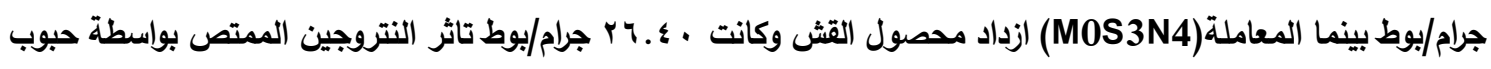

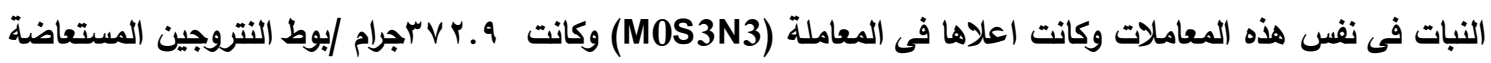

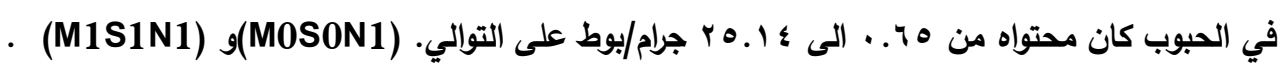

أ. أ.د/ على أحمد عبدالسلام كلية الزراعة - جامعة بنها

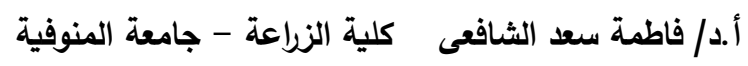

